points out, can publish two Nature papers in a year - but students and postdocs in that lab might see their PI only twice in that year.

Sönmezer feels that he doesn't need to worry about being overlooked or ignored. Krebs is committed to his success, and for good reason. The first couple of years can make or break a lab, so PIs will do what they can to keep everyone moving in a positive, productive direction. And because the PIs are often still early-career scientists, they might be better able to offer career advice than more-senior faculty members elsewhere. "I do feel some responsibility for Arnaud's career," Sönmezer says. "He has my back, so I feel like I have to have his."

Even though he has a lot of contact with his PI, Sönmezer has also found a degree of independence. In a larger lab, he could have expected lots of guidance from postdocs. But as his lab's only trainee, he has to work things out for himself. "It's challenging because no one is there to tell me to put tubes here and solutions there," he says. "It's timeconsuming, but it's a good career investment."

\section{NEW LAB, BIG IDEAS}

Imbeault thinks that his lab has another selling point: he's investigating a hot topic that could lead to several discoveries - and the papers to match. Specifically, he is scrutinizing a class of proteins that have an important but little-understood role in DNA binding. "You could make a big discovery here that we can't even predict," he says. "There is more potential for novelty."

Imbeault is quick to add that not all labs conform to generalizations. Some longentrenched labs manage to pursue hot topics, and some new

PIs are already out of fresh ideas.

Likewise, some

big-name PIs

manage to devote

plenty of time

to their trainees,

and some new PIs

"You could make a big discovery

here that we

can't even predict.There is more potential for novelty."

rarely make an appearance. In the end, he says, the age of a lab isn't as important as how the lab works.

Fessenden says that he feels fortunate to be in Spranger's lab. "She's so easy-going and unstressed," he says. "She brought homemade cookies and mulled wine to a lab meeting. She wants us to be relaxed and happy."

For him, it all goes back to a piece of advice he got from a chief executive of a large drug company. "He told me, 'Wherever you work, make sure you're working with interesting, motivated people.' I took that to heart." -

Chris Woolston is a freelance writer in Billings, Montana.

INDIA

\title{
Website tells
} women's stories

\section{Resource celebrates the careers of India's female scientists.}

\section{BY HARINI BARATH}

$\mathrm{T}$ wo science journalists in India continue to build on The Life of Science, a multimedia website that they designed and launched in 2016 to highlight the research and lives of more than 100 women in the country.

The site, founded and run by Nandita Jayaraj and Aashima Dogra, aims to chronicle the scientists' experiences in the lab and field. Jayaraj and Dogra, who work full-time on the site, compile feature stories, blogposts, podcasts, video and picture features about the women, whose work spans the fields of science, technology, engineering and mathematics (STEM).

The journalists met in 2014 in Bangalore, while working on a now-defunct children's science magazine. When this shut down in 2015, they decided to explore their mutual interest in science communication. Dogra had already planned to travel the country on a brief busman's holiday, and visited the Indian Agricultural Research Institute in Kalimpong to talk to women who worked there. Meanwhile, Jayaraj was interviewing geophysicist Kusala Rajendran at the Indian Institute of Science in Bangalore and biophysicist Aruna Dhathathreyan at the Central Leather Research Institute in Chennai.

When the two journalists conferred about the information they had gathered, they decided to create a website to publicize the stories. "We were curious about the science under way in laboratories in our back yard," says Jayaraj about the site's early days. "We also wanted to break the stereotype of the scientist as an old male person." As the two began writing full-time, they crowdfunded for their work on the Indian platform BitGiving.

Jayaraj and Dogra have since launched a second campaign to fund their work on the site, which includes compiling some of the content into two books.

Each scientist's story offers a glimpse into her world - from the physical environment in which she lives and works, to the nature of her research and how she reached her present position. "I particularly like how the narratives let us see the woman behind the science and scientific journey," says Vidita Vaidya, a neuroscientist at the Tata Institute of Fundamental Research in Mumbai, who is featured on the site.

The site showcases India's diverse research

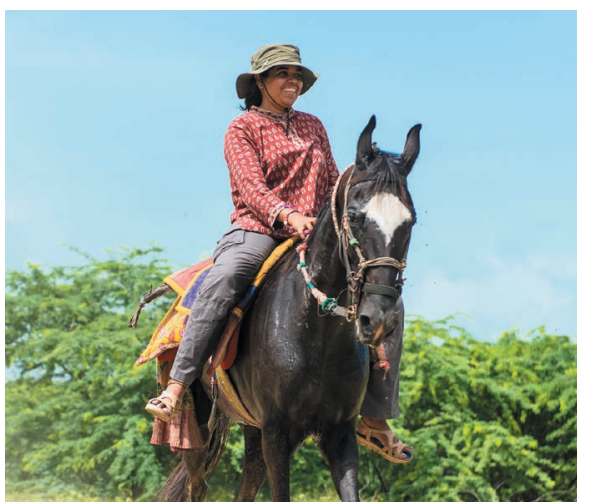

The Life of Science profiles ecologist Ovee Thorat.

landscape. Some of the scientists work with state-of-the-art equipment such as dilution refrigerators, confocal microscopes and highperformance computing clusters; others make the most of sparse funds and scant supplies.

Yet the stories' common threads resonate with many others who aspire to, or are navigating, a scientific career: the struggles to balance family life and career, and to counter bias and stereotypes.

The interviewees offer ideas for ameliorating some of the struggles, such as establishing campus child-care facilities and promoting female scientists into leadership positions. "Nothing on this scale has ever been done before," says Vaidya. She hopes that the site can help bring together those who are profiled, as well as other women who work in STEM in India.

Jayaraj and Dogra continue to find more women to profile. Viewer numbers and other metrics are not available, but the developers intend to continue the site in perpetuity. Indian online news sites including The Wire and Firstpost have syndicated some of the articles.

Those profiled are delighted at the chance to connect with readers. Number theorist Kaneenika Sinha at the Indian Institute of Science Education and Research in Pune has received e-mails from parents seeking suggestions for training their mathematically talented child, junior scientists who plan to repatriate and want 'insider' information, and students with questions about her work.

Jayaraj and Dogra are experimenting with different formats, including photo stories, cartoons and podcasts. "We see The Life of Science not really as an entity or 'our' project," the two say, "but what it stands for - and that is the voices of women in science." 